\title{
Comparison of antioxidant activity of extracts of hop leaves harvested in different years
}

\author{
ANNA MUZYKIEWICZ*, ANNA NOWAK, JOANNA ZIELONKA-BRZEZICKA, KATARZYNA \\ FLORKOWSKA, WIKTORIA DUCHNIK, ADAM KLIMOWICZ
}

\begin{abstract}
Chair and Department of Cosmetic and Pharmaceutical Chemistry
Pomeranian Medical University

Powstańców Wielkopolskich 72

70-111 Szczecin, Poland

*corresponding author: phone: 489146616 30, fax: 489146618 49,

e-mail: anna.muzykiewicz@pum.edu.pl
\end{abstract}

\section{Summary}

Introduction: Hop (Humulus lupulus L.) is a common plant in Europe, with many beneficial health effects. In addition to the use in brewing, hops are a valuable source of active substances used in conventional and folk medicine, such as humulones and lupulones, as well as antioxidants, including phenolic compounds.

Objective: The aim of the study was to evaluate and compare the antioxidant activity of alcoholic extracts of fresh hop leaves collected in 2017 and 2018.

Material and methods: The raw material consisting of fresh hop leaves was extracted using ultrasoundassisted extraction. Methyl, ethyl and isopropyl alcohol at three concentrations were used as extractants. The antioxidant activity of extracts was determined using DPPH and FRAP methods. Total phenolic content was evaluated using the Folin-Ciocalteu technique.

Results: All the extracts showed antioxidant potential as well as the phenolic content. Regardless of the harvesting year and methods of evaluation, the highest antioxidant activity and the total polyphenol content were observed for extracts prepared in undiluted methanol, obtained during one hour lasting extraction.

Conclusion: The results of the studies have suggested that hop leaves can be a potential source of healthpromoting antioxidants.

Key words: Humulus lupulus L., DPPH, Folin-Ciocalteu method, FRAP, antioxidants, ultrasoundassisted extraction

Słowa kluczowe: Humulus lupulus L., DPPH, metoda Folin-Ciocalteu, FRAP, antyoksydanty, ekstrakcja wspomagana ultradźwiękami 


\section{INTRODUCTION}

Common hop (Humulus lupulus L.) is a dioecious, perennial climbing plant of the Cannabaceae family. It is found mainly in deciduous forests and thickets of Europe and western Asia, but also in other temperate climate zone areas. It develops underground rhizomes with flagellums, and its above-ground shoots can reach up to $10 \mathrm{~m}$ in height as wrapping around the support [1-3]. The female flowers without the perianth form strobiles - characteristic inflorescences resembling the appearance of cones, whereas the male with the flowers are grouped in bunches. Female hops are cultivated for industrial purposes, as a valuable brewing or medicinal raw material $[1,2,4]$.

In addition to primary metabolites present in different parts of the hop, including sugars (glucose, fructose, raffinose and maltose), lipids (sitosterol derivatives), amino acids (tryptophan), peptides and proteins, this plant is a source of many valuable secondary metabolites with biological activity. They include terpenoids (mono- and sesquiterpenes), a large group of phenolic compounds (chalcones, flavanones, flavonols, flavan-3-ols, phenolic acids, tannins, stilbenes and lignans), as well as alkaloids, bitter acids (humulones and lupulones) and others (tab. 1) $[1,2,5,6]$.

These compounds are responsible for among other antibacterial, antioxidant, chemopreventive, anticollagenic, estrogenic, anti-inflammatory action. They also could influence on enzyme activity and factors involved in the processes of tumorigenesis or cell apoptosis activity [2,7]. Flower cones, known as hops, besides brewing, are used in conventional and folk medicine, homeopathy or cosmetology, as diastolic, analgesic, antiulcer, antiallergic, regenerating, bactericidal, fungicidal and diuretic agents. In addition to beer production, they are also used to make liqueurs, oils, infusions, capsules, dragees or ointments $[7,8]$. Hops are also a source of lupulin - a substance with a sedative and hypnotic effect, from the surface of female cones, which fills the hops glandular hair - so-called hops glands [2, 7, 9]. Similar properties show farnesene, humulone and lupulone - used to treat mood disorders, including anxiety or insomnia [3, 4]. Hop preparations inhibit the activity of the cerebral cortex and excessive agitation. Due to their estrogenic activity, which is connected to 8-prenylnaringenin content, hops extracts are also used to relieve the menopause symptoms $[3,10]$. H. lupulus L. compounds, in particular xanthohumol and lupulone, show antibacterial and anti-inflammatory activity, which may affect the acne causes and bacterial infections symptoms, by reducing the development of the genus Staphylococcus, Streptococcus or Propionibacterium [11-13]. The mentioned xanthohumol may also inhibit the multiplication of virus causing viral bovine diarrhea, cytomegalovirus, herpes simplex or HIV, as

Table 1.

Selected examples of secondary metabolites present in $H$. lupulus L. $[1,2,5,6]$

\begin{tabular}{|c|c|}
\hline \multicolumn{2}{|r|}{ TERPENOIDS } \\
\hline Monoterpenes & d-limonene, $\beta$-myrcene, $\alpha$-, $\beta$-pinene, $\beta$-phellandrene \\
\hline Sesquiterpenes & $\alpha$-humulene, $\beta$-caryophyllene, $\alpha$-, $\beta$-farnesene $\alpha$-, $\beta$-, $\delta$-selinene, $\alpha$-zingiberene \\
\hline Other terpenoids & $\alpha-, \beta-, \delta$-amyrin, lupeol \\
\hline \multicolumn{2}{|r|}{ PHENOLIC COMPOUNDS } \\
\hline Chalcones & $\begin{array}{l}\text { xanthohumol, xanthohumols B, C, D, E, G, H, I, M, desmethylxanthohumol, } \\
\text { xanthogalenol, flavokavine }\end{array}$ \\
\hline Flavanones & isoxanthohumol, naringenin, 8-prenylnaringenin \\
\hline Flavonols and their glycosides & quercetin, kaempferol, myricetin, rutin \\
\hline Flavan-3-ols & catechin, epicatechin, epigallocatechin, gallocatechin \\
\hline Tannins & catechin and epicatechin derivatives, prodelphinidin $\mathrm{B}_{3}$, procyanidin $\mathrm{B}_{1}, \mathrm{~B}_{2}, \mathrm{~B}_{3}, \mathrm{~B}_{4}, \mathrm{C}_{1}, \mathrm{C}_{2}$ \\
\hline Phenolic acids & $p$-coumaric acid, ferulic acid, cinnamic acid, hydroxycinnamic acid, gallic acid \\
\hline Lignans & isolariciresinol, pinoresinol \\
\hline Stilbens & resveratrol \\
\hline \multicolumn{2}{|r|}{ ALKALOIDS } \\
\hline \multicolumn{2}{|l|}{ Tetrahydro- $\beta$-carboline } \\
\hline \multicolumn{2}{|r|}{ BITTER ACIDS } \\
\hline$\alpha$-Acids - humulones & ad-, co-, pre-, post-, deoxy- and isohumulone, humulone A, B, C \\
\hline$\beta$-Acids - lupulones & ad-, co-, pre-, postlupulone, lupulone C, E, G i H \\
\hline
\end{tabular}


well as Trichophyton species dermatophytes. The active substances contained in hops have a chemopreventive effect, so may be valuable ingredients of an anti-cancer diet rich in antioxidants $[13,14]$. Hops stipule extracts can be successfully used to prevent caries and periodontal diseases [15].

Moreover, various parts of this plant favorably affect urinary and digestive system, reduce cholesterol level, risk of ulcers development and high blood pressure, seal blood vessels and have a positive effect in relieving rheumatic pains $[2,7,11,12,16]$.

The aim of the study was to evaluate and compare antioxidant activity of alcoholic extracts of fresh H. lupulus L. leaves collected in 2017 and 2018. The effect of solvent and extraction time on antioxidant potential of extracts was evaluated.

\section{MATERIAL AND METHODS}

Reagents used in this research were purchased from Sigma-Aldrich, USA: 6-hydroxy-2,5,7,8-tetramethylchroman-2-carboxylic acid (Trolox), 2,2-diphenyl-1-picrylhydrazyl (DPPH), 2,4,6-tripyridyl-Striazine (TPTZ); from Merck, Darmstadt, Germany: iron(II) sulphate heptahydrate, the Folin-Ciocalteu reagent and gallic acid; from Chempur, Poland: iron(III) chloride hexahydrate, sodium carbonate anhydrous, $36 \%$ hydrochloric acid, sodium acetate anhydrous, methanol, $99.5 \%$ acetic acid and isopropyl alcohol - all of analytical grade and from Linegal Chemicals, Poland - 96\% (v/v) ethyl alcohol.

The raw material consisted of wild $H$. lupulus L. leaves and was collected from natural sites in Szczecin. To evaluate antioxidant activity and polyphenols content at the beginning of hop vegetation, upper and young leaves were used to obtain the extracts. Fresh hop leaves harvested in May in two consecutive years were applied as raw material. $0.5 \mathrm{~g}$ of fresh material was extracted with $10 \mathrm{~cm}^{3}$ of solvent using ultrasound-assisted extraction of $40 \mathrm{kHz}$ in 15, 30 and 60 minutes at a room temperature. Polar solvents as methanol $(\mathrm{MeOH})$, ethanol $(\mathrm{EtOH})$ and isopropanol (IsoProOH) as well as their aqueous solutions in three concentrations for each: 40, 70 and $96-99.5 \%(v / v)$ were applied for extraction.

The antioxidant activity as well as total polyphenols content of extracts were evaluated with methods based on spectrophotometric measurements - DPPH, FRAP and Folin-Ciocalteu (F-C) method, using previously described techniques [1718]. Three independent samples were prepared for each extract. The obtained results are presented as arithmetic mean \pm standard deviation (SD).

To evaluate antioxidant activity, the DPPH method was applied, where $0.3 \mathrm{mM}$ ethanolic solution of DPPH was diluted to the absorbance of $1.00 \pm 0.02$. Then, to $2850 \mu \mathrm{l}$ of diluted reagent, $150 \mu \mathrm{l}$ of extract was added and incubated at a room temperature for $10 \mathrm{~min}$. Absorbance was taken at $517 \mathrm{~nm}$ using $10 \mathrm{~mm}$ cuvettes. Based on the absorbance and calibration curve for Trolox as a standard, Trolox equivalent activity concentration (TEAC) was calculated and expressed as mg Trolox/g raw material. Moreover, the percentage of extracts radical scavenging activity - RSA was also calculated based on formula:

$$
\operatorname{RSA}[\%]=\left(1-\mathrm{A}_{\mathrm{s}} / \mathrm{A}_{\mathrm{o}}\right) \cdot 100 \%
$$

where $A_{s}$ is the absorbance of tested sample and $A_{0}$ - the absorbance of blank sample.

Ferric ion reducing power of extracts was determined using FRAP method. The working solution consisted of 1 volume of $10 \mathrm{mM}$ TPTZ solution in $40 \mathrm{mM} \mathrm{HCl}, 1$ volume of $20 \mathrm{mM} \mathrm{FeCl}_{3}$ and 10 volumes of acetate $0.3 \mathrm{M}$ buffer ( $\mathrm{pH}$ 3.6) was prepared. Aliquots of $2320 \mu \mathrm{l}$ of such solution with $80 \mu \mathrm{l}$ of extract were mixed and after $15 \mathrm{~min}$ incubation at room temperature their absorbance in $1 \mathrm{~cm}$ cuvettes at $593 \mathrm{~nm}$ was taken. The results were expressed as $\mathrm{FeSO}_{4}$ equivalents [ $\mathrm{mg} \mathrm{FeSO}_{4} / \mathrm{g}$ raw material].

Folin-Ciocalteu (F-C) method was applied to total polyphenol content evaluation of hop leaves extracts. The $10 \% \mathrm{~F}-\mathrm{C}$ reagent solution was prepared and incubated $1 \mathrm{~h}$ in dark at room temperature. Then, to $2700 \mu \mathrm{l}$ of $5 \mathrm{mM} \mathrm{Na}_{2} \mathrm{CO}_{3} 150 \mu \mathrm{l}$ extract and $150 \mu \mathrm{l}$ of previously prepared F-C solution was added and incubated for 15 minutes at room temperature. Absorbance was taken at $750 \mathrm{~nm}$. Total polyphenol content was expressed as gallic acid (GA) equivalents [mg GA/g raw material].

Statistical significance of differences between antioxidant activity of extracts of hop leaves harvested in 2017 and 2018, as well as between the results obtained with use of different methods of evaluation (DPPH, FRAP, F-C) were assessed using the Wilcoxon test (parameter $\mathrm{z}$ ), assuming the significance level $\alpha=0.05$. The Pearson correlations coefficients ( $\mathrm{r}$ ) between antioxidant potential of extracts from raw material harvested in two consecutive years were also estimated. Statistical analyses of the results were done using Statistica 13.1 (Statsoft, Poland) as well as Prostat 5.5 (Poly Software International, USA).

Ethical approval: The conducted research is not related to either human or animal use. 


\section{RESULTS}

Antioxidant activity of $H$. lupulus extracts of leaves collected in different years is presented in table 2 . All evaluated extracts show antioxidant potential. Regardless of the collecting year and methods of evaluation, the highest properties were found for extracts prepared in concentrated methanol during one-hour ultrasound-assisted extraction. The lowest potential was found for extracts in $70 \%(v / v)$ isopropyl alcohol, where the extraction time was 15 minutes. The exception was a group of extracts made from leaves collected in 2017 and evaluated by F-C method, where the lowest polyphenols level was found for the sample prepared in $70 \%(v / v)$ methanol in $30 \mathrm{~min}$. extraction.

Antioxidant potential of hop leaves collected in 2017 evaluated with DPPH method ranged between $0.26 \pm 0.02$ and $3.67 \pm 0.13 \mathrm{mg}$ Trolox/g raw material (tab. 2), which corresponded to RSA $11.67 \pm 0.31 \%$ to $78.33 \pm 2.46 \%$ (fig. 1 ). The statistically significant differences (estimated by the Wilcoxon test) were found between the activity of extracts made from leaves collected in individual years evaluated using DPPH method $(\mathrm{z}=-2.427$, $p=0.015)$. Moreover, significant Pearson's correlation coefficient $(\mathrm{r}=0.622 ; p<0.001)$ was found between these groups of results.

The antiradical potential of leaves extracts collected in 2017 evaluated with FRAP method ranged

Table 2.

Total phenol content and antioxidant activity of extracts of hop leaves, collected in different years, evaluated with Folin-Ciocalteu, DPPH and FRAP methods (mean \pm SD)

\begin{tabular}{|c|c|c|c|c|c|c|c|}
\hline \multicolumn{2}{|l|}{ Year of collection } & 2017 & 2018 & 2017 & 2018 & 2017 & 2018 \\
\hline \multirow{4}{*}{$\begin{array}{l}\text { Solvent } \\
\\
98 \%(v / v) \\
\mathrm{MeOH}\end{array}$} & $\begin{array}{c}\text { Extraction } \\
\text { time } \\
{[\mathrm{min}]}\end{array}$ & \multicolumn{2}{|c|}{$\begin{array}{c}\text { DPPH } \\
{[\mathrm{mg} \text { Trolox/g raw material] }}\end{array}$} & \multicolumn{2}{|c|}{$\begin{array}{c}\text { FRAP } \\
{\left[\mathrm{mg} \mathrm{FeSO}_{4} / \mathrm{g} \text { raw material }\right]}\end{array}$} & \multicolumn{2}{|c|}{$\begin{array}{c}\text { Folin-Ciocalteu } \\
{[\text { mg GA/g raw material }]}\end{array}$} \\
\hline & 15 & $2.97 \pm 0.03$ & $2.65 \pm 0.09$ & $4.20 \pm 0.04$ & $4.25 \pm 0.03$ & $3.41 \pm 0.14$ & $3.20 \pm 0.05$ \\
\hline & 30 & $3.18 \pm 0.17$ & $0.95 \pm 0.01$ & $4.28 \pm 0.15$ & $6.08 \pm 0.02$ & $3.17 \pm 0.26$ & $1.10 \pm 0.04$ \\
\hline & 60 & $3.67 \pm 0.13$ & $3.72 \pm 0.00$ & $7.44 \pm 0.04$ & $8.55 \pm 0.02$ & $6.60 \pm 0.26$ & $6.22 \pm 0.15$ \\
\hline \multirow{3}{*}{$\begin{array}{l}70 \%(v / v) \\
\mathrm{MeOH}\end{array}$} & 15 & $3.50 \pm 0.12$ & $2.68 \pm 0.08$ & $3.80 \pm 0.43$ & $3.22 \pm 0.01$ & $3.91 \pm 0.20$ & $1.72 \pm 0.11$ \\
\hline & 30 & $0.98 \pm 0.03$ & $1.57 \pm 0.11$ & $0.95 \pm 0.14$ & $2.48 \pm 0.01$ & $0.51 \pm 0.11$ & $1.24 \pm 0.09$ \\
\hline & 60 & $2.88 \pm 0.17$ & $3.62 \pm 0.04$ & $3.12 \pm 0.01$ & $4.46 \pm 0.01$ & $2.69 \pm 0.25$ & $2.80 \pm 0.20$ \\
\hline \multirow{3}{*}{$\begin{array}{l}40 \%(v / v) \\
\mathrm{MeOH}\end{array}$} & 15 & $2.93 \pm 0.17$ & $1.46 \pm 0.09$ & $4.51 \pm 0.05$ & $2.11 \pm 0.02$ & $4.15 \pm 0.23$ & $0.95 \pm 0.09$ \\
\hline & 30 & $2.98 \pm 0.02$ & $1.59 \pm 0.07$ & $5.03 \pm 0.26$ & $2.61 \pm 0.02$ & $4.94 \pm 0.14$ & $1.19 \pm 0.01$ \\
\hline & 60 & $2.89 \pm 0.11$ & $1.75 \pm 0.02$ & $4.24 \pm 0.03$ & $2.65 \pm 0.05$ & $3.20 \pm 0.09$ & $1.20 \pm 0.01$ \\
\hline \multirow{3}{*}{$\begin{array}{l}96 \%(v / v) \\
\mathrm{EtOH}\end{array}$} & 15 & $2.83 \pm 0.10$ & $1.35 \pm 0.02$ & $3.51 \pm 0.01$ & $3.78 \pm 0.03$ & $3.46 \pm 0.11$ & $2.83 \pm 0.26$ \\
\hline & 30 & $2.46 \pm 0.04$ & $3.21 \pm 0.09$ & $3.22 \pm 0.03$ & $6.17 \pm 0.03$ & $3.04 \pm 0.05$ & $4.46 \pm 0.44$ \\
\hline & 60 & $2.46 \pm 0.19$ & $2.53 \pm 0.03$ & $2.66 \pm 0.03$ & $6.04 \pm 0.02$ & $2.64 \pm 0.28$ & $3.94 \pm 0.25$ \\
\hline \multirow{3}{*}{$\begin{array}{l}70 \%(v / v) \\
\mathrm{EtOH}\end{array}$} & 15 & $2.14 \pm 0.18$ & $1.39 \pm 0.07$ & $2.12 \pm 0.16$ & $1.91 \pm 0.01$ & $2.01 \pm 0.24$ & $1.03 \pm 0.06$ \\
\hline & 30 & $3.07 \pm 0.14$ & $3.69 \pm 0.02$ & $3.62 \pm 0.07$ & $6.29 \pm 0.03$ & $3.27 \pm 0.15$ & $5.23 \pm 0.33$ \\
\hline & 60 & $3.61 \pm 0.03$ & $3.31 \pm 0.10$ & $6.18 \pm 0.11$ & $4.09 \pm 0.02$ & $5.58 \pm 0.26$ & $2.90 \pm 0.04$ \\
\hline \multirow{3}{*}{$\begin{array}{l}40 \%(v / v) \\
\mathrm{EtOH}\end{array}$} & 15 & $0.94 \pm 0.03$ & $0.37 \pm 0.09$ & $0.75 \pm 0.10$ & $1.24 \pm 0.02$ & $0.67 \pm 0.11$ & $0.09 \pm 0.03$ \\
\hline & 30 & $3.11 \pm 0.05$ & $2.20 \pm 0.17$ & $2.55 \pm 0.28$ & $3.43 \pm 0.01$ & $4.12 \pm 0.11$ & $2.08 \pm 0.08$ \\
\hline & 60 & $3.35 \pm 0.08$ & $2.66 \pm 0.06$ & $7.19 \pm 0.47$ & $3.75 \pm 0.03$ & $6.44 \pm 0.21$ & $2.34 \pm 0.18$ \\
\hline \multirow{3}{*}{$\begin{array}{l}99.5 \%(v / v) \\
\text { IsoProOH }\end{array}$} & 15 & $1.34 \pm 0.02$ & $1.22 \pm 0.07$ & $1.20 \pm 0.07$ & $3.79 \pm 0.04$ & $1.08 \pm 0.16$ & $2.00 \pm 0.17$ \\
\hline & 30 & $1.12 \pm 0.01$ & $0.99 \pm 0.05$ & $0.70 \pm 0.01$ & $3.50 \pm 0.03$ & $0.76 \pm 0.01$ & $1.95 \pm 0.18$ \\
\hline & 60 & $2.14 \pm 0.11$ & $0.96 \pm 0.09$ & $2.56 \pm 0.08$ & $3.86 \pm 0.01$ & $2.48 \pm 0.13$ & $2.26 \pm 0.13$ \\
\hline \multirow{3}{*}{$\begin{array}{l}70 \%(v / v) \\
\text { IsoProOH }\end{array}$} & 15 & $0.26 \pm 0.02$ & $0.13 \pm 0.00$ & $0.30 \pm 0.03$ & $1.02 \pm 0.02$ & $0.56 \pm 0.11$ & $0.02 \pm 0.01$ \\
\hline & 30 & $2.25 \pm 0.10$ & $2.74 \pm 0.14$ & $2.44 \pm 0.13$ & $4.49 \pm 0.47$ & $2.58 \pm 0.25$ & $3.44 \pm 0.33$ \\
\hline & 60 & $3.56 \pm 0.04$ & $1.00 \pm 0.08$ & $5.22 \pm 0.02$ & $3.58 \pm 0.02$ & $5.47 \pm 0.07$ & $2.58 \pm 0.23$ \\
\hline \multirow{3}{*}{$\begin{array}{l}40 \%(v / v) \\
\text { IsoProOH }\end{array}$} & 15 & $1.88 \pm 0.11$ & $0.47 \pm 0.01$ & $2.69 \pm 0.17$ & $1.36 \pm 0.03$ & $2.03 \pm 0.26$ & $0.54 \pm 0.11$ \\
\hline & 30 & $0.58 \pm 0.05$ & $1.40 \pm 0.01$ & $0.86 \pm 0.04$ & $2.66 \pm 0.02$ & $0.75 \pm 0.13$ & $1.11 \pm 0.05$ \\
\hline & 60 & $3.42 \pm 0.15$ & $3.55 \pm 0.11$ & $7.28 \pm 0.05$ & $5.88 \pm 0.07$ & $6.56 \pm 0.21$ & $3.64 \pm 0.29$ \\
\hline
\end{tabular}

$\alpha<0.05$ 


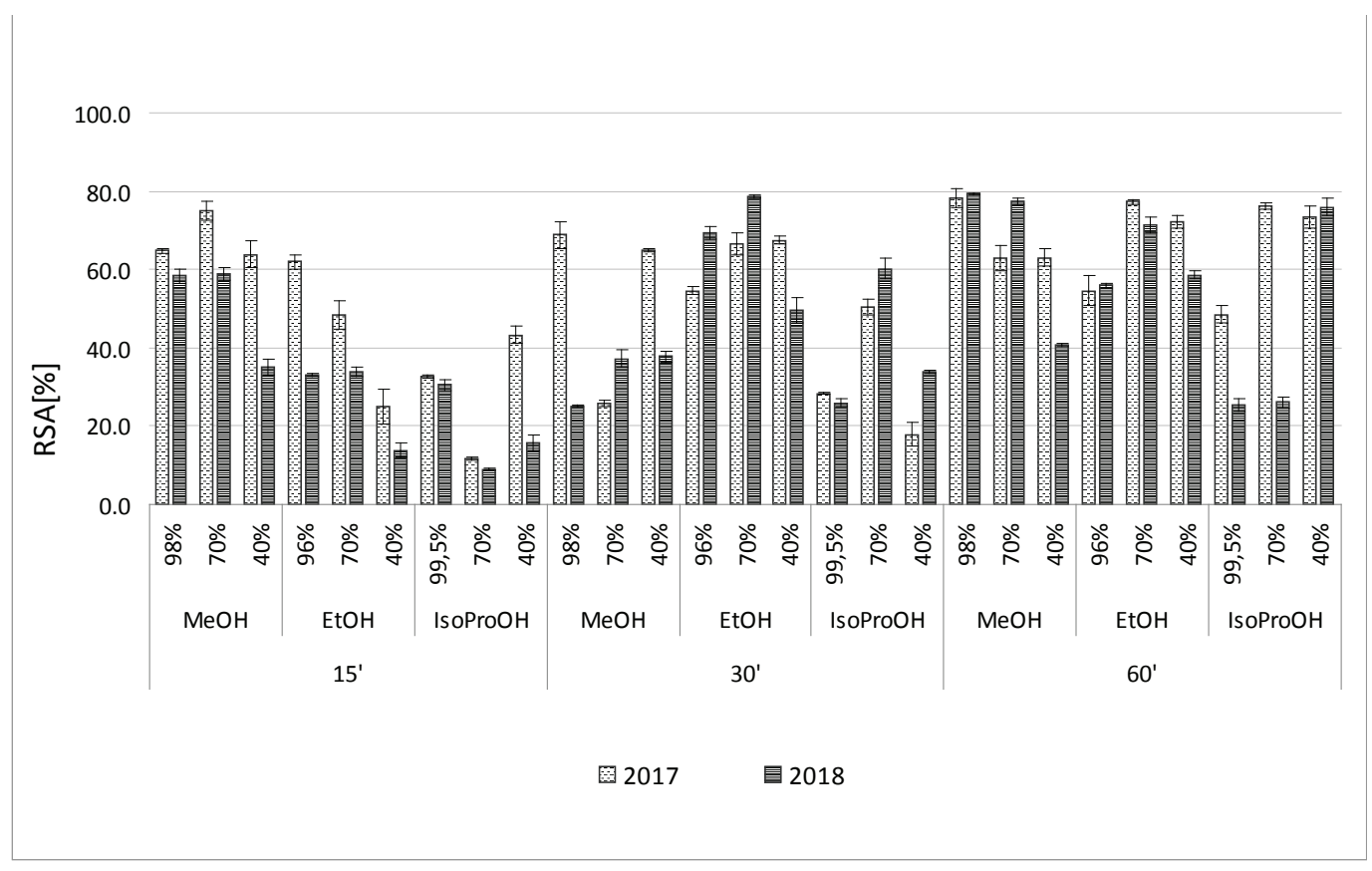

Figure 1.

Mean radical scavenging activity [\%] of hop leaves extracts evaluated with DPPH method. Vertical lines represent standard deviation (SD)

from $0.30 \pm 0.03$ to $7.44 \pm 0.04 \mathrm{mg} \mathrm{FeSO} / \mathrm{g}$ raw material, for 2018 year from $1.02 \pm 0.02$ to $8.55 \pm 0.02 \mathrm{mg}$ $\mathrm{FeSO}_{4}$ /g raw material (tab. 2). Differences between the activity of leaves collected in particular years were statistically insignificant, however they correlated with each other significantly $(\mathrm{r}=0.515, p=0.006)$.

Total polyphenol content of leaves collected in 2017, evaluated with F-C method, ranged between $0.51 \pm 0.11$ and $6.60 \pm 0.26 \mathrm{mg} \mathrm{GA} / \mathrm{g}$ raw material, whereas such properties of raw material collected one year later was between $0.02 \pm 0.01$ and $6.22 \pm 0.15 \mathrm{mg}$ GA/g of raw material (tab. 2). Statistical significant differences were found between potential of extracts of hop leaves collected in different years $(\mathrm{z}=-2.258$; $p=0.024)$ and these results correlated to each other significantly taking into account the same solvent applied for extraction $(\mathrm{r}=0.499 ; p=0.008)$.

\section{DISCUSSION}

H. lupulus L. has been used as an ingredient in herbal preparations with sedative, estrogenic, antiinflammatory, anti-viral, antibacterial and anticancer properties $[2,19]$. High antioxidant potential of this plant has been proved by others [2, 11, 20-23]. The most often analyzed raw material of hop are cones. There are few reports on antioxidant potential and the content of biologically active ingredients in other parts of the plant, such as leaves, stems or roots. Choi et al. compared the antioxidant activity of extracts from leaves, stems and roots of Japanese hop (H. japonicus Siebold \& Zucc) using DPPH and FRAP methods. They proved that hop leaves are a more valuable source of antioxidants as compared to other evaluated raw materials. The highest prohealth polyphenols content was also found in leaves [24]. The high antioxidant activity of hop leaves extracts was also confirmed in our study. The antioxidant potential evaluated with DPPH method was the highest in case of extracts prepared in concentrated methanol (60 minutes), in the first as well as in the second year of collection $(3.67 \pm 0.13$ and $3.72 \pm 0.00 \mathrm{mg}$ Trolox/g raw material).

Considering antiradical properties evaluated with FRAP method, higher potential was found for methanolic extracts in undiluted extractant - in 2017: 7.44 \pm 0.04 and in 2018: $8.55 \pm 0.02 \mathrm{mg} \mathrm{FeSO}_{4} / \mathrm{g}$ raw material (tab. 2). Önder et al. found the antioxidant potential of hop cone extracts, to be $14.95 \mu \mathrm{g}$ Trolox/100 g extract when assessed by DPPH and $1.56 \mathrm{mmol} \mathrm{Fe} e^{2+} / \mathrm{g}$ extract, in the case of FRAP analysis [23]. Yumaguchi et al. also confirmed the high antioxidant activity of hop cone extracts, determined by the ORAC (oxygen radical absorbance capacity) method [11].

The ability to scavenge free radicals by plant extracts depends on the content of some compounds such as polyphenols [2, 25-27]. These compounds, due to their antioxidant properties, may also show 
among others anti-cancer or anti-inflammatory effects [26]. Researchers found higher polyphenols content in leaves extracts than in other raw materials, such as flowers, fruit or roots of the same plant $[24,28,29]$. In our study, polyphenols content in hop leaves ranged between $0.51 \pm 0.11$ and $6.60 \pm 0.26 \mathrm{mg}$ $\mathrm{GA} / \mathrm{g}$ raw material in 2017 and from $0.02 \pm 0.01$ to $6.22 \pm 0.15 \mathrm{mg} \mathrm{GA} / \mathrm{g}$ raw material in 2018 was found (tab. 2). Similarly to previous methods, the higher total polyphenol content was found in methanolic extracts prepared during one hour ultrasoundassisted extraction. The total polyphenol content varied between the extracts. It may be partly due to the different extraction conditions. The studied extracts were prepared in three different alcohols. Moreover, three concentrations of aqueous solution of each alcohol were used to obtain the extracts. Taking into account that polyphenols solubility varied between solvents, the differences between total polyphenol content in examined extracts could depend, among others, on solvent and extraction time. The results obtained in our study were confirmed by others. Proestos et al. determined total polyphenol content in hop leaves at $2.9 \mathrm{mg} \mathrm{GA} / \mathrm{g}$ dry mass of raw material [30]. Choi et al. compared the content of polyphenols in different parts of hop and found the highest concentration in leaves $(3089.9 \mathrm{mg} / \mathrm{kg}$ fresh weight), as compared to stem (1313.9 mg/kg fresh weight) or roots $(655.2 \mathrm{mg} / \mathrm{kg}$ fresh weight $)$ [24]. On the other hand, cones tested by Önder et al. showed the content of these compounds at a level of 8343-9079 mg ferrulic acid/100 g extract [23]. Moreover, the interesting source of valuable biologically active substances seems to be young shoots, in which Maietti et al. found the flavonoids content, from 517 to $2698 \mu \mathrm{g} / \mathrm{g}$ fresh weight, depending on the plant variety [21].

The solvent type is an important factor in the extraction process, having a major impact on the antioxidant activity of obtained plant extracts [31, 32]. In our study, three polar alcohols (methanol, ethanol and isopropanol) differing, inter alia, in the length of the molecule carbon chain were used as solvents. Regardless the measurement method applied, the higher antioxidant potential was found in extracts made using concentrated methanol, while the lowest, in most cases, extracts in 70\% $(v / v)$ isopropanol. Also, the prolongation of the extraction time had a positive effect on the activity of obtained extracts (tab. 2). Methyl alcohol is often used to prepare plant extracts including also $H$. lupulus L. raw material [21, 30]. Zielonka-Brzezicka et al. reported that the most effective extractant to pineapple parts
(Ananas comosus) extraction, taking into account radical scavenging activity [\%] of obtained extracts, seemed to be concentrated methanol. This alcohol showed better extraction capabilities against ingredients of plant antioxidants than the other applied polar alcohols, such as $70 \%$ and $96 \%(v / v)$ ethanol [33]. Also, Önder et al. confirmed the methanol and ethanol efficacy in the extraction of polyphenols from $H$. lupulus L., evaluated by the Folin-Ciocalteu method [23]. Nowak et al. observed higher antioxidant concentrations in Ginkgo biloba leaves extracts prepared in $40 \%$ and $70 \%(v / v)$ ethanol as compared to those in concentrated methanol [27]. According to Pawlak and Sielicka, except the concentration of the applied solvent for extraction, also its polarity seems to be crucial. These authors showed the highest content of phenolic compounds in extracts of chokeberry (Aronia melanocarpa) made with a 50\% aqueous solution of acetone [34].

The method and time of extraction are also important factors which may affect the activity of the obtained plant extracts. In our study, the highest antioxidant potential, including the total polyphenol content, was found in extracts prepared using an ultrasonic bath for 60 minutes, while the lowest was obtained during the 15-min. extraction. These results confirm the results of studies on other plants, in which the extension of ultrasound-assisted extraction time led to increase of antioxidant activity of prepared extracts $[28,33,35]$. It is worth mentioned, that ultrasound-assisted extraction is considered as so-called green extraction technique. Wang et al. suggested that application of ultrasounds for plant material extraction is beneficial mainly due to the lower use of solvents than in classical techniques, and as a consequence to less adverse environmental impact [36]. Taking into account the influence of various factors on antioxidant activity of extracts, it should be mentioned that there are no universal extraction method, and therefore, the choice of extraction procedure should be individually selected for particular plant raw material [37].

The results of presented study show that the date of plant material harvesting may have a significant impact on their antioxidant activity, as well as the technique of extraction. In our study hop leaves were collected from the same place during the same vegetation stage, but in different years. The statistically significant differences estimated with the Wilcoxon test were found between the activity of extracts from different harvesting years (except for the FRAP method results). One of important factor responsible for these differences seems to be different 
climatic conditions in particular years, which could be one of the main reasons for the content of biologically active substances in plants diversity [38]. Variable weather conditions can cause environmental stress, having a significant impact on the plant secondary metabolites profile [39].

\section{CONCLUSION}

1. The extracts of young hop leaf harvested at the beginning of vegetation, showed high antioxidant activity.

2. The antioxidant potential of $H$. lupulus leaves extracts was influenced by several factors, such as type of solvent or time of extraction. The most effective process seems to be one hour ultrasoundassisted extraction in undiluted methanol.

3. Antioxidants content differed depending on the plant material harvesting time. This parameter may be also influenced by environmental factors, such as climatic conditions.

4. Hop leaves extracts seems to be a valuable source of natural antioxidants to be applied in different industry branches.

Conflict of interest: Authors declare no conflict of interest.

\section{REFERENCES}

1. Bocquet L, Sahpaz S, Hilbert JL, Rambaud C, Rivière C. Humulus lupulus L., a very popular beer ingredient and medicinal plant: overview of its phytochemistry, its bioactivity, and its biotechnology. Phytochem Rev 2018; 17(5):1047-1090. doi: http://dx.doi.org/10.1007/s11101-018-9584-y

2. MielczarekM, KołodziejczykJ, Olas B. Właściwości lecznicze chmielu zwyczajnego (Humulus lupulus L.). Post Fitoter 2010; 11(4):205-210

3. Nowak G. Surowce roślinne o działaniu przeciwlękowym i antydepresyjnym. Herba Pol 2009; 55(1):84-97.

4. Dobros N. Zioła o działaniu uspokajającym i przeciwdepresyjnym. Post Fitoter 2017; 18(3):215-222. doi: http://dx.doi.org/10.25121/ PF.2017.18.3.215
5. Sbardella M, Racanicci AM., Gois FD, de Lima CB, Migotto DL, Costa LB et al. Effects of dietary hop (Humulus lupulus L.) $\beta$-acids on quality attributes, composition and oxidative stability of pork meat. J Sci Food Agric 2018; 98(6):23852392. doi: http://dx.doi.org/10.1002/jsfa. 8730

6. Yan DD, Wong YF, Shellie RA, Marriott PJ, Whittock SP, Koutoulis A. Assessment of the phytochemical profiles of novel hop (Humulus lupulus L.) cultivars: A potential route to beer crafting. Food Chem 2019; 275:15-23. doi: http://dx.doi. org/10.1016/j.foodchem.2018.09.082

7. Kutsenko S, Gerbina N. Substantiation of the medicine with dry extract of hop cones in the form of hard gelatine capsules for treatment of gastrointestinal diseases development expediency. Technol Trans Innov Sol Med 2017: 48-51. doi: http://dx.doi.org/10.21303/2585-663.2017.00447

8. Alonso-Esteban JI, Pinela J, Barros L, Ćirić A, Soković M, Calhelha RC et al. Phenolic composition and antioxidant, antimicrobial and cytotoxic properties of hop (Humulus lupulus L.) Seeds Ind Crops Prod 2019; 134:154-159. doi: http://dx.doi. org/10.1016/j.indcrop.2019.04.001

9. Killeen DP, Watkins OC, Sansom CE, Andersen DH, Gordon KC, Perry NB. Fast sampling, analyses and chemometrics for plant breeding: bitter acids, xanthohumol and terpenes in lupulin glands of hops (Humulus lupulus). Phytochem Anal 2017; 28(1):50-57. doi: http://dx.doi. org $/ 10.1002 /$ pca. 2642

10. Aghamiri V, Mirghafourvand M, MohammadAlizadeh-Charandabi S, Nazemiyeh H. The effect of Hop (Humulus lupulus L.) on early menopausal symptoms and hot flashes: A randomized placebo-controlled trial. Complement Ther Clin Pract 2016; 23:130-135. doi: http://dx.doi. org/10.1016/j.ctcp.2015.05.001

11. Yamaguchi N, Satoh-Yamaguchi K, Ono M. In vitro evaluation of antibacterial, anticollagenase, and antioxidant activities of hop components (Humulus lupulus) addressing acne vulgaris. Phytomed 2009; 16(4):369-376. doi: http://dx.doi. org/10.1016/j.phymed.2008.12.021

12. Gerhäuser C. Broad spectrum antiinfective potential of xanthohumol from hop (Humulus lupulus L.) in comparison with activities of other hop 
constituents and xanthohumol metabolites. Mol Nutr Food Res 2005; 49(9):827-831. doi: http:// dx.doi.org/10.1002/mnfr.200500091

13. Wyszkowska-Kolatko M, Koczurkiewicz P, Wójcik K, Pękala E. Rośliny lecznicze w terapii chorób skóry. Post Fitoter 2015; 16(3):184-192.

14. Dietz BM, Kang YH, Liu G, Eggler AL, Yao P, Chadwick LR et al. Xanthohumol isolated from Humulus lupulus inhibits menadione-induced DNA damage through induction of quinone reductase. Chem Res Toxicol 2005; 18(8):12961305. doi: http://dx.doi.org/10.1021/tx050058x

15. Tanaka Y, Yanagida A, Komeya S, Kawana M, Honma D, Tagashira $\mathrm{M}$ et al. Comprehensive separation and structural analyses of polyphenols and related compounds from bracts of hops (Humulus lupulus L.). J Agric Food Chem 2014; 62(10):21982206. doi: http://dx.doi.org/10.1021/jf405544n

16. Olsovska J, Bostikova V, Dusek M, Jandovska V, Bogdanova K, Cermak P et al. Humulus lupulus L. (hops) - a valuable source of compounds with bioactive effects for future therapies. Mil Med Sci Lett 2016; 85(1):19-30. doi: http://dx.doi. org/10.31482/mmsl.2016.004

17. Muzykiewicz A, Zielonka-Brzezicka J, Klimowicz A. Quince (Cydonia oblonga Mill.) as a useful source of antioxidants - antioxidant activity evaluation. Herba Pol 2018; 64(4):23-33. doi: http:// dx.doi.org/10.2478/hepo-2018-0020

18. Muzykiewicz A, Zielonka-Brzezicka J, Klimowicz A. Antioxidant potential of Hippophae rhamnoides L. extracts obtained with green extraction technique. Herba Pol 2018; 64(4):14-22. doi: http://dx.doi.org/10.2478/hepo-2018-0022

19. Matławska I. Farmakognozja. $1^{\text {st }}$ ed. Poznań. Akademia Medyczna im. Karola Marcinkowskiego w Poznaniu, 2005:364-366.

20. Nuutinen T. Medical properties of terpenes found in Cannabis sativa and Humulus lupulus. Eur J Med Chem 2018; 157:198-228. doi: http://dx.doi. org/10.1016/j.ejmech.2018.07.076.

21. Maietti A, Brighenti V, Bonetti G, Tedeschi P, Prencipe FP, Benvenuti S et al. Metabolite profiling of flavonols and in vitro antioxidant activity of young shoots of wild Humulus lupulus L. (hop). J
Pharm Biomed Anal 2017; 142:28-34. doi: http:// dx.doi.org/10.1016/j.jpba.2017.04.043

22. Wang $X$, Yang $L$, Yanga $X$, Tian $Y$. In vitro and in vivo antioxidant and antimutagenic activities of polyphenols extracted from hops (Humulus lupulus L.). J Sci Food Agric 2014; 94(8):1693-1700. doi: http://dx.doi.org/10.1002/jsfa.6534

23. Önder FC, Ay M, Sarker SD. Comparative study of antioxidant properties and total phenolic content of the extracts of Humulus lupulus L. and quantification of bioactive components by LC-MS/MS and GC-MS. J Agric Food Chem 2013; 61(44):10498-10506. doi: http://dx.doi. org/10.1021/jf4031508

24. Choi JY, Desta KT, Lee SJ, Kim YH, Shin SC, Kim GS et al. LC-MS/MS profiling of polyphenol-enriched leaf, stem and root extracts of Korean Humulus japonicus Siebold \& Zucc and determination of their antioxidant effects. Biomed Chromatogr 2018; 32:1-8. doi: http://dx.doi.org/10.1002/bmc.4171

25. Kołodziej B, Drożdżal K. Właściwości przeciwutleniające kwiatów i owoców bzu czarnego pozyskiwanego ze stanu naturalnego. Żywn Nauk Technol Ja 2011; 4(77):36-44.

26. Zalega J, Szostak-Węgierek D. Żywienie w profilaktyce nowotworów. Część I. Polifenole roślinne, karotenoidy, błonnik pokarmowy. Probl Hig Epidemiol 2013; 94(1):41-49.

27. Nowak A, Zielonka-Brzezicka J, Pechaiko D, Tkacz M, Klimowicz A. Ocena właściwości antyoksydacyjnych liści Ginkgo biloba L. po zakończeniu wegetacji. Pomeranian J Life Sci 2017; 63(1):9-15. doi: http://dx.doi.org/10.21164/ pomjlifesci.222

28. Muzykiewicz A, Zielonka-Brzezicka J, Klimowicz A, Florkowska K. Jarząb pospolity (Sorbus aucuparia L.) jako źródło składników o potencjalnym działaniu antyoksydacyjnym - porównanie właściwości przeciwutleniających ekstraktów z liści, kwiatów i owoców. Probl Hig Epidemiol 2017, 98(2):125-132.

29. Zielonka-Brzezicka J, Nowak A, Zielińska M, Klimowicz A. Porównanie właściwości przeciwutleniających wybranych części maliny właściwej (Rubus idaeus) i jeżyny europejskiej (Rubus fruticosus). Pomeranian J Life Sci 2016; 
62(4):52-59. doi: http://dx.doi.org/10.21164/ pomjlifesci.269.

30. Proestos C, Boziaris IS, Nychas GJE, Komaitis M. Analysis of flavonoids and phenolic acid in Greek aromatic plants: Investigation of their antioxidant capacity and antimicrobial activity. Food Chem 2006; 95(4):664-671. doi: http://dx.doi. org/10.1016/j.foodchem.2005.01.049

31. Gawlik-Dziki U, Kowalczyk D. Wpływ warunków ekstrakcji na aktywność przeciwutleniającą ekstraktów z kiełków rzodkiewki. Żywn Nauk Technol Ja 2007; 1(50):132-139.

32. Wianowska D, Wiśniewski M. Simplified procedure of silymarin extraction from Silybum marianum L. Gaertner. J Chrom Sci 2015; 53(2):366372. doi: http://dx.doi.org/10.1093/chromsci/ bmu049

33. Zielonka-Brzezicka J, Nowak A, Klimowicz A, Duchnik W, Wira D, Wysocka D et al. Ocena aktywności antyoksydacyjnej ananasa jadalnego (Ananas comosus). Pomeranian J Life Sci 2018; 64(3):132-138. doi: http://dx.doi.org/10.21164/ pomjlifesci.456

34. Pawlak S, Sielicka M. Wpływ rozpuszczalnika zastosowanego do ekstrakcji na oznaczoną zawartość związków fenolowych i aktywność przeciwutleniającą wytłoków z aronii. In: Górecka D, Pospiecha E (eds.). Zagospodarowanie ubocznych produktów przemysłu spożywczego. $1^{\text {st }}$ ed. Poznań. Uniwersytet Przyrodniczy, Poznań 2016:25-33.

35. Florkowska K, Duchnik W, Nowak A. Klimowicz A. Właściwości antyoksydacyjne papryki ostrej odmiany Hungarian yellow. Pomeranian J Life Sci 2018; 64(3):126-131. doi: http://dx.doi. org/10.21164/pomjlifesci.455

36. Wang J, Sun B, Cao Y. Optimisation of ultrasound-assisted extraction of phenolic compounds from wheat bran. Food Chem 2008; 106(2):804-810. doi: http://dx.doi.org/10.1016/j. foodchem.2007.06.062

37. Azwanida NN. A review on the extraction methods use in medicinal plants, principle, strength and limitation. Med Aromat Plants 2015; 4(3):3-8. doi: http://dx.doi.org/10.4172/21670412.1000196

38. Łata B, Wińska-Krysiak M, Lewandowska J. Potencjał przeciwutleniający owoców borówki wysokiej w zależności od odmiany i roku badań. Rocz AR Poz 2007; 383(41):399-344.

39. Sati P, Pandey A, Rawat S, Rani A. Phytochemicals and antioxidants in leaf extracts of Ginkgo biloba with reference to location, seasonal variation and solvent system. J Pharm Res 2013; 7(9):804-809. doi: http://dx.doi.org/10.1016/j.jopr.2013.09.001. 